\title{
Hariring Indung Sebagai Media Komunikasi Ibu dan Anak Usia Dini
}

\author{
Andalusia Neneng Permatasari, Dinar Nur Inten \\ Fakultas Ilmu Komunikasi dan Fakultas Tarbiyah dan Keguruan, \\ Universitas Islam Bandung, Jl Tamansari No 1, Bandung \\ andalusia@unisba.ac.id,dinar_nurinten@unisba.ac.id
}

\begin{abstract}
Communicating with early childhood is certainly not the same as communicating with children in high school or adolescent. There needs to be a way that adults can enter the world of early childhood so that there is no distance between parents and children. When the distance is no longer stretched, the child will be more comfortable to express and convey his heart. This study aims to provide information and examine the use of the hariring indung in Lamajang Village, Pangalengan District, Bandung as a medium of communication between mothers and early childhood. Hariring Indung is a humming activity performed by a mother when putting her to sleep, accompanying play, and other activities with her child. Hariring Indung is part of the sekar tradition in Sundanese culture. Hariring Indung is a way for mothers to build communication with their children so that the relationship between mother and child will be more intimate. The theory used in this study is the theory of nursery rhymes and family communication. The research method used is quantitative with a descriptive analysis approach. Data collection was carried out by giving a questionnaire to 35 young mothers who had early childhood. The results of this study indicate that mothers in Lamajang Village, Pangalengan District, Bandung are still using Hariring Indung as a medium for communicating with their children. Through the indung day, mothers in Lamajang Village, Pangalengan District, Bandung send messages and hopes to their children. With the habits of mothers in Lamajang Village, Pangalengan District, Bandung, the Hariring Indung tradition which is a Sundanese tradition can be preserved and maintained.
\end{abstract}

Keywords: early childhood, education communication, family communication, Sunda

\begin{abstract}
Abstrak
Berkomunikasi dengan anak usia dini tentu tidak akan sama dengan berkomunikasi anak di usia sekolah dasar kelas atas dan remaja. Perlu ada suatu cara yang membuat orang dewasa dapat masuk ke dunia anak usia dini sehingga tidak ada jarak antara orang tua dengan anak. Ketika sudah tidak ada jarak membentang, anak akan lebih nyaman untuk mengekspresikan dan menyampaikan isi hatinya. Penelitian ini bertujuan memberikan informasi dan mengkaji penggunaan hariring indung oleh ibu-ibu di Desa Lamajang, Kecamatan Pangalengan, Kabupaten Bandung sebagai media komunikasi antara ibu dan anak usia dini. Hariring Indung adalah kegiatan bersenandung yang dilakukan seorang ibu ketika menidurkan, menemani bermain, dan aktivitas lainnya bersama anak. Hariring Indung termasuk tradisi sekar dalam kebudayaan Sunda. Hariring Indung adalah cara ibu membangun komunikasi bersama anak sehingga hubungan ibu dan anak akan semakin intim. Teori yang digunakan pada penelitian ini adalah teori tentang nursery rhymes dan
\end{abstract}


komunikasi keluarga. Metode penelitian yang digunakan adalah kuantitatif dengan pendekatan analisis deskriptif. Pengumpulan data dilakukan dengan memberikan angket pada 35 orang ibu muda yang memiliki anak usia dini. Hasil dari penelitian ini menunjukkan bahwa ibu-ibu di Desa Lamajang, Kecamatan Pangalengan, Kabupaten Bandung masih menggunakan hariring indung sebagai media untuk berkomunikasi dengan anak. Melalui hariring indung, ibu-ibu di di Desa Lamajang, Kecamatan Pangalengan, Kabupaten Bandung menyelipkan pesan dan harapan kepada anaknya. Dengan kebiasaan dari ibu-ibu di Desa Lamajang, Kecamatan Pangalengan, Kabupaten Bandung, tradisi hariring indung yang merupakan tradisi Sunda dapat dilestarikan dan dipertahankan.

Kata Kunci: anak usia dini, komunikasi keluarga, komunikasi pendidikan, Sunda

\section{Pendahuluan}

Kekayaan Indonesia bukan saja terletak pada kekayaan alam dan sumber daya alamnya. Kekayaan Indonesia yang sering kali terlupakan adalah bahasa daerah dan tradisi yang dimiliki setiap daerah. Menurut hasil survei BPS (Badan Pusat Statistik) tahun 2010, Indonesia memiliki 1.340 suku bangsa (Welianto, 2020). Setiap suku bangsa ini memiliki bahasa daerahnya masing-masing. Salah satu suku bangsa yang ada di Indonesia adalah Suku Sunda.

Suku Sunda adalah kelompok etnis yang berasal dari bagian Barat pulau Jawa, yaitu Jawa Barat. Suku Sunda di Indonesia terdapat sekitar 39.701.670 orang atau 15,5\% dari total penduduk Indonesia (Badan Pusat Statistik, 2015). Suku Sunda juga sebagian dapat ditemui di daerah Banten dan sebagian Jawa Tengah. Selayaknya suku bangsa lain yang ada di Indonesia, suku Sunda pun memiliki bahasa daerah, tradisi, kearifan lokal, dan kekayaan folklore. Salah satu kearifan lokal sekaligus kekayaan folklore yang dimiliki suku Sunda adalah hariring indung. Hariring artinya bersenandung atau berdendang (Sumantri et al., 1985).

Sifat dari hariring adalah ngahariring tara tarik, artinya 'dibawakan secara halus'. Pemakaian kata dalam lagu lebih menonjol, cenderung bernyanyi untuk diri sendiri, pengisi jiwa (berupa nasihat), cenderung improvisasi terutama ketika sedang gembira. Hariring indung biasanya dilakukan para ibu sambil menidurkan anak (harewos indung memeh sare). Namun, tidak hanya saat akan menidurkan anak, hariring indung dilakukan juga saat anak bermain, saat anak sakit, dan sesekali di waktu mandi. Hariring indung berisikan harapan seorang ibu terhadap anaknya, berupa doa-doa dan nasihat-nasihat (mepeling).

Di masa lalu, sejak lahir orang Sunda telah didekatkan dengan alunan sekar. Sekar dalam tradisi Sunda adalah seni suara yang dalam substansi dasarnya mempergunakan suara manusia (Setiaji, 2017). Sekar merupakan karya seni yang erat berhubungan langsung dengan indra pendengaran. Sejak dulu, orang Sunda menimang, meninabobokan, mengajak beramin, sampai belajar berjalan dan berbicara pun sekar sangat intens dilantunkan oleh ibu.

Tembang atau nyanyian yang biasa didendangkan saat menimang, meninabobokan, dan menyenang-nyenangkan anak di tiap daerah memiliki ciri khas masing-masing. Nyanyian sejenis hariring indung antara lain adalah puisipuisi anak, lagu atau tembang dolanan, baik dalam bahasa Indonesia maupun dalam 
Andalusia Neneng Permatasari, Dinar Nur Inten: Hariring Indung Sebagai Media Komunikasi Ibu dan Anak Usia Dini

berbagai bahasa daerah. Dalam bahasa Inggris dikenal dengan sebutan nursery rhymes atau nursery songs (Nurgiantoro, 2016).

Nursery rhymes tidak harus berupa syair-syair lagu yang dinyanyikan, melainkan dapat dan sering hanya berupa bunyi musik, nyanyian vokal, senandung, pengulangan bunyi-bunyi, irama-irama sederhana yang mendapat penekanan atau bunyi-bunyi bersajak dan berirama jelas, dan ketukan-ketukan tangan yang berirama yang dikenal sebagai finger rhymes (Nurgiantoro, 2016). Curahan hati kasih sayang orang tua terhadap anak lewat puisi-puisi lagu dolanan ketika meninabobokan dan menimang bersifat universal sesuai dengan latar belakng budayanya, seperti seorang ibu di masyarakat sunda yang menyanyikan lagu ayun ambing saat meninabobokan anaknya.

Lagu sangat identik dengan anak, terutama dalam hal ini adalah anak usia dini. Lagu dan permainan sangat diminati anak-anak (Otto, 2015). Lagu tidak hanya berfungsi sebagai hiburan bagi anak usia dini, tetapi juga bersifat didaktis atau sebagai pendidikan. Dengan lagu, anak usia dini dapat belajar aneka hal. Dari lagu juga, anak usia dini, yaitu anak yang berumur $0-8$ tahun dapat meningkatkan kecakapan dalam berbicara dan berbahasa (Inten et al., 2016). Penggabungan antara ritme nyanyian dan gerakan sederhana serta pengulangan pertma akan menambah perbendaharaan kosa kata anak. Oleh karena itu, dalam pembelajaran di kelas juga, menyanyi adalah metode yang tepat dalam mengajarkan anak usia dini untuk mencintai buku (Permatasari et al., 2017).

Lagu yang cocok dengan anak usia dini adalah (1) lagu harus relevan, penuh makna, dan menarik anak-anak; (2) lagu mengandung cerita singkat yang sesuai dengan dunia anak-anak; (3) melodi lagu haruslah singkat dan mudah diingat anakanak; (4) lagu sebaiknya berisi informasi apa yang perlu dipelajari anak di masa yang akan datang; (5) lagu sebaiknya mengulang informasi dan keterampilan praktis yang dapat dilakukan anak-anak; dan (6) lagu sebaiknya dapat diapresiasi anak-anak sesuai umurnya (Rachmani, 2008). Lagu akan menstimulus anak untuk merespons secara verbal, seperti gumaman atau senandung yang terpatah-patah karena belum bisa mengartikulasikan suatu kata dengan baik. Selain secara verbal, anak juga biasa merespons sebuah lagu dengan nonverbal, seperti senyuman atau gerakan tangan. Dengan respons itulah, anak usia dini mulai berkomunikasi.

Berkomunikasi dengan anak usia dini tentu tidak akan sama dengan berkomunikasi anak di usia sekolah dasar kelas atas dan remaja. Perlu ada suatu cara yang membuat orang dewasa dapat masuk ke dunia anak usia dini sehingga tidak ada jarak antara orang tua dengan anak. Ketika sudah tidak ada jarak membentang, anak akan lebih nyaman untuk mengekspresikan dan menyampaikan isi hatinya. Apalagi anak usia dini yang dalam tahap perkembangan kognitifnya masih pada tahap pra-operasional. Pada tahap ini, pemaknaan terhadap sesuatu masih berdasarkan pemaknaannya sendiri (Permatasari, 2017). Salah satu cara untuk menjalin kedekatan dalam berkomunikasi dengan anak adalah dengan mengatur posisi duduk atau dengan mimik wajah. Orang tua berkomunikasi dengan anak menggunakan ekspresi mimik dan gerak sehingga anak dapat memahami pesan yang disampaikan (Triwardhani, 2009). 
Komunikasi yang terbaik adalah saat anak dapat memahami hal-hal yang disampaikan oleh orang tuanya. Anak-anak di bawah usia dua tahun belum begitu mahir untuk berkomunikasi secara verbal, maka orang tua sebaiknya memperbanyak komunikasi dengan bahasa tubuh. Beberapa cara komunikasi yang dapat dilakukan orang tua dengan anak melalui bahasa tubuh, yaitu (1) tatap mata anak saat berbicara, (2) ekspresi wajah lebih banyak berbicara, dan (3) gunakan bahasa tubuh yang positif (Istadi, 2012).

Walaupun anak-anak di bawah usia dua tahun lebih dominan melakukan komunikasi secara isyarat atau bahasa tubuh dan lebih banyak terjadi komunikasi satu arah yaitu dari orang tua terhadap anak, tetapi sebenarnya mereka selalu mencoba memahami pesan yang disampaikan dan berusaha merespon balik komunikasi yang terjadi. Oleh karena itu, orang tua terutama ibu harus berusaha memahami bahasa atau komunikasi yang disampaikan oleh anak dan tetap meningkatkan kualitas dan kuantitas komunikasi dengan anak-anak karena sesuangguhnya anak adalah perekam yang ulung. Pentingnya peran keluarga di dalam perkembangan bahasa anak, anak-anak yang berada di dalam keluarga yang lebih banyak intensitas berbicaranya cenderung memiliki perkembangan bahasa yang levelnya lebih tinggi pada perkembangan dan penggunaan kosakata sehingga hal ini sangat mempengaruhi kemampuan anak dalam berkomunikasi.

Bagi ibu-ibu di tanah Sunda, terutama di daerah kabupaten seperti Desa Lamajang, Kecamatan Pangalengan, Kabupaten Bandung, salah satu cara berkomunikasi dengan anak adalah dengan cara hariring indung. Ibu-ibu menyanyikan senandung dengan bahasa Sunda yang penuh makna, baik itu mendoakan kesehatan anak, mendoakan kesuksesan anak, dan harapan-harapan baik lainnya. Berikut ada beberapa penelitian terdahulu yang fokus penelitiannya adalah nursery rhymes. Dalam hal ini, hariring indung dianggap sebagai salah satu bentuk dari nursery rhymes.

Pertama, penelitian sebelumnya terkait nursery rhymes yang memiliki irisan dengan penelitian ini ditulis oleh Brittany Nixon May (May, 2020) dengan judul "The Rhyme and Reason for Nursery Rhymes in the Elementary Music Classroom". Nursery rhymes dapat menstimulus kemampuan kognitif, fisik, sosial, emosional, dan musikalitas seorang anak (May, 2020). Hal ini pun telah banyak disadari oleh para pengajar sehingga nursery rhymes diajarkan juga di ruang kelas. Penelitian ini menyimpulkan bahwa nursery rhymes memberi para pengajar peluang untuk mengajarkan sesuatu yang bersifat interdisipliner yang memfasilitasi kebutuhan, ketertarikan, dan kemampuan siswa mereka.

Penelitian terdahulu yang membahas nursery rhymes adalah penelitian yang berjudul “Improving Young Learner's Listening Skill By Using Nursery Rhymes Song" (Putri et al., 2018). Kemampuan menyimak adalah skill penting yang harus dimiliki anak usia dini ketika mempelajari bahasa asing. Penelitian ini menggunakan metode penelitian tindakan kelas untuk melihat perbedaan dari kelas yang diajarkan bahasa dengan nursery rhymes dan kelas yang tidak menggunakan nursery rhymes dalam pembelajaran bahasa. Hasil dari penelitian ini memperlihatkan bahwa nursery rhymes dapat membantu siswa untuk meningkatkan kemampuan berbahasa asing secara signifikan. Nursery Rhymes membantu siswa untuk menguasai kemampuan menyimak (listening) dengan baik. 
Andalusia Neneng Permatasari, Dinar Nur Inten: Hariring Indung Sebagai Media Komunikasi Ibu dan Anak Usia Dini

Oleh karena itu, nursery rhymes adalah salah satu media yang efektif untuk meningkatkan kemampuan menyimak dalam pembelajaran bahasa Inggris bagi anak usia dini karena dengan bernyanyi mereka lebih bahagia ketika belajar.

Ada lagi penelitian sebelumnya yang membahas tentang makna dari lagulagu yang termasuk nursery rhymes, yaitu penelitian yang berjudul "Meaning and Form in Nursery Rhymes Translation". Penelitian ini menunjukkan urgensi penerjemahan yang baik untuk lagu-lagu yang termasuk nursery rhymes karena sangat berpengaruh terhadap perkembangan seorang anak. Hasil dari penelitian menunjukkan masih banyak lagu-lagu anak yang termasuk nursery rhymes diterjemahkan ke dalam Bahasa Indonesia dengan salah. Padahal, nursery rhymes itu memiliki yang sangat penting dalam tahapan perkembangan anak-anak.

Ada juga penelitian terdahulu yang terkait dengan komunikasi antara ibu dan anak. Pertama, penelitian yang berjudul "Pengaruh Komunikasi Interpersonal Ibu dan Anak terhadap Kemampuan Berbicara Anak". Penelitian ini bertujuan mengkaji pengaruh komunikasi interpersonal terhadap kemampuan berbicara anak usia 4-5 tahun. Metode yang digunakan adalah metode expost facto dengan sampel 48 orang siswa. Hasil penelitian ini memperlihatkan adanya pengaruh positif antara komunikasi interpersonal terhadap kemampuan berbicara anak usia 4-5 tahun. Oleh karena itu, jika komunikasi interpersonal ibu kepada anak ditingkatkan, maka meningkat pula kemampuan berbicara anak (Riza, 2016).

Penelitian sebelumnya yang pernah dilakukan adalah "Strategi Komunikasi terhadap Anak Usia Dini”. Penelitian ini menghasilkan bahwa komunikasi harus dikembangkan dengan strategi yang disesuaikan dengan tingkat pertumbuhan dan perkembangan anak. Komunikasi lisan yang dilakukan dengan anak harus memperhatikan tiga hal penting, yaitu penggunaan istilah yang tepat dan dipahami anak, berkesinambungan atau tidak boleh terputus-putus, serta adanya aba-aba atau sinyal ketika akan berpindah tema percakapan (Bahri, 2018).

Selanjutnya, ada penelitian berjudul "Pola Komunikasi Interpesonal Orang Tua dan Anak Usia Dini dengan Speech Delay di TK Aisyiyah Rewwin Waru". Penelitian ini bertujuan mengetahui pola komunikasi interpersonal yang terjadi antara orang tua dan anak dengan speech delay. Metode pengumpulan data dengan wawancara mendalam dan observasi. Hasil penelitian menunjukkan peran orang tua dalam menjalin pola komunikasi interpersonal sangat mempengaruhi perilaku anak usia dini. Oleh karena itu, orang tua harus menerapkan pola yang baik terhadap anak usia dini dengan speech delay. Selain itu, orang tua pun perlu menjaga hubungan yang intens untuk mengurangi dampak dari speech delay yang dialami anak (Liansari, 2017).

Perbedaan penelitian ini dengan penelitian-penelitian sebelumnya adalah jenis nursery rhymes pada penelitian ini khusus yang mengandung kearifan lokal, yaitu kearifan lokal dari tanah dan tradisi Sunda. Selain itu, penelitian fokus pada hariring indung sebagai media komunikasi ibu dan anak di desa Lumajang, Kecamatan Pangalengan, Kabupaten Bandung. Berdasarkan penjelasan di atas, tampak adanya keterkaitan yang erat antara hubungan orang tua dan anak dalam hal kemampuan berkomunikasi anak usia dini. Oleh karena itu, penelitian ini memiliki tujuan untuk memperoleh informasi dan mengkaji penggunaan hariring indung 
oleh ibu-ibu di Desa Lamajang, Kecamatan Pangalengan, Kabupaten Bandung sebagai media komunikasi antara ibu dan anak usia dini.

\section{Metode Penelitian}

Penelitian ini menggunakan metode analisis deskriptif, yaitu melihat kebiasaan yang berhubungan dengan hariring indung yang dilakukan oleh para ibu yang memiliki anak usia dini. Subjek dari penelitian ini adalah ibu-ibu muda yang memiliki anak usia dini di Desa Lamajang, Kecamatan Pangalengan, Kabupaten Bandung. Adapun objek dari penelitian ini adalah ibu-ibu dari siswa usia dini yang bersekolah di R.A. Al-Muqoddasah, Desa Lumajang, Kecamatan Pangalengan, Kabupaten Bandung. Desa Lamajang ini masih sangat kental tradisi Sunda yang diperlihatkan oleh kebiasaan-kebiasaan warganya. Teknik pengambilan data dari penelitian ini adalah melalui kuesioner yang diberikan kepada 35 orang ibu muda tersebut. Hasil kuesioner dianalisis berdasarkan teori para ahli dan dideskripsikan menjadi sebuah penelitian yang mudah dipahami oleh banyak orang. Teknik validasi data dilakukan dengan cara instrumen penelitian ini dinilai (di-judgment) oleh pakar atau ahli komunikasi keluarga dan anak usia dini.

\section{Hasil Penemuan dan Diskusi}

Sifat dasar dan pola pengasuhan mempengaruhi perkembangan individu. Aspek komunikasi yang penting dialami anak sebagai bayi adalah pola saling bertukar peran dalam percakapan atau dialog interaktif. Hal-hal yang disampaikan ibu kepada anaknya di antaranya tentang pembelajaran, pengalaman, dan nilai-nilai yang ingin disosialisasikan kepada anak agar mereka dapat belajar langsung (Nurhadi, 2015). Baik itu dari pengalaman ibu atau dari lirik hariring yang dilantunkan ibu. Ketika ibu melantunkan hariring maka bayi ikut berperan aktif di dalam percakapan baik lisan ataupun non lisan sehingga tanpa disadari komunikasi pun dapat terbangun dengan baik. Bahasa tidak diperoleh dengan pengamatan tetapi dengan menggunakannya (Otto, 2015).

Sejak dilahirkan anak langsung dapat mendengarkan berbagai kata yang diucapkan atau dituturkan oleh orang-orang di sekitarnya. Kata-kata yang didengarnya bisa berupa nyanyian atau hariring indung yang disenandungkan seorang ibu ketika menidurkan atau mengajak anak bermain. Berdasarkan data yang diperoleh, 60\% ibu yang melakukan hariring menggunakan kawih Sunda atau Bahasa sunda yang diciptakan oleh si ibu sendiri, sedangkan $40 \%$ mengiringi tidur anak dengan sholawat dan kawih atau lagu dengan Bahasa Indonesia. 


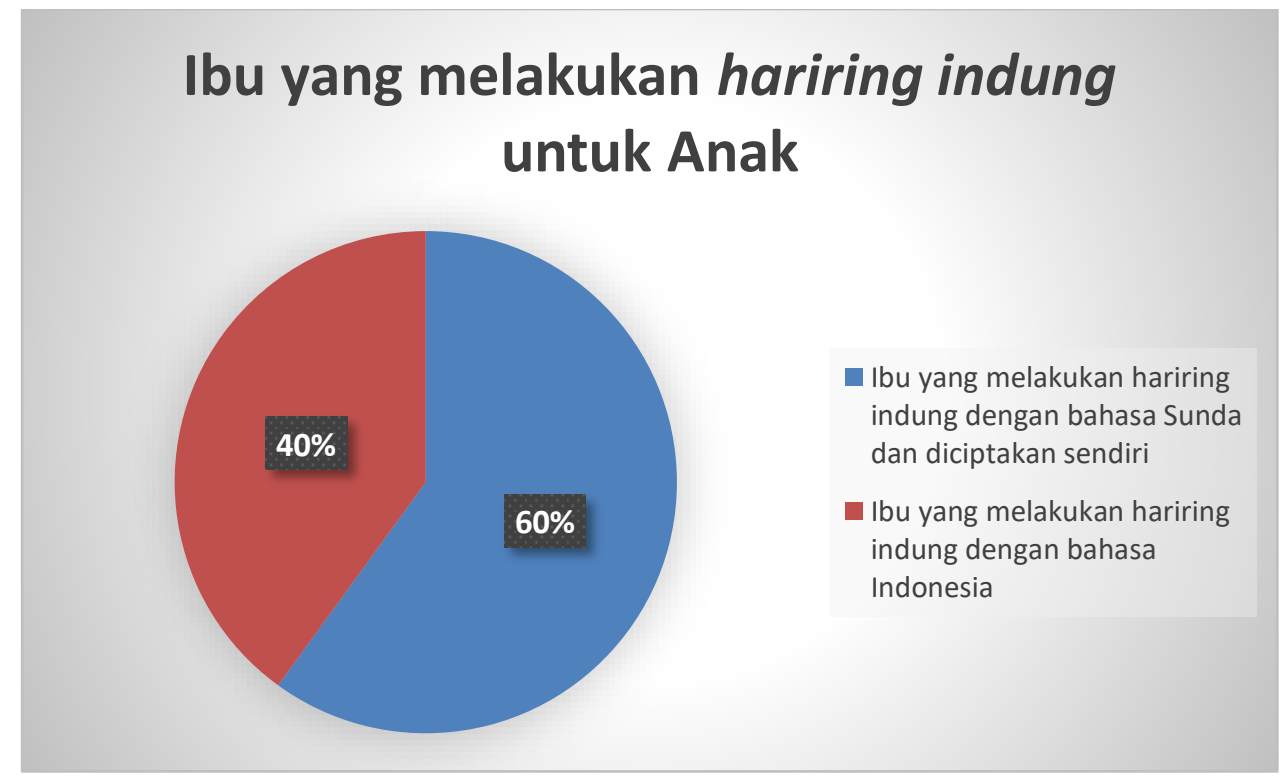

Gambar 1: Ibu Yang Melakukan Hariring Indung Untuk Anak

Ketika sang ibu ngahariring adakan kontak mata dan sentuhan dengan bayi ataupun batita yang digendong atau diajak main sehingga komunikasi pun dapat terjalin dengan baik. Ucapan yang berupa hariring disampaikan dengan ekspresif dan beragam secara intonasi hal ini akan menarik perhatian anak. Gunakan pula kata secara berulang-ulang agar pemahaman bayi akan hal-hal yang disampaikan mudah dipahaminya dan orang dewasa dalam hal ini ibu, harus konsisten dalam menyampaikan kata-kata. Oleh karena itu, 60\% ibu menggunakan hariring ciptaan sendiri agar mudah disampaikan pada anak dan sesuai dengan keadaan anak.

Hariring indung dapat membangun kelekatan antara ibu dan anak. Ibu adalah orang yang memiliki intensitas tinggi bersama anak. Hariring indung dapat menjadi media bagi ibu untuk berkomunikasi dengan anak usia dini yang relatif sulit jika diajak berkomunikasi secara formal. Setidaknya, Hariring indung dapat membangun komunikasi ibu dan anak secara perlahan karena komunikasi yang diberikan orang tua (dalam hal ini ibu) kepada anak akan menentukan kualitas diri anak. Hubungan yang lekat dan intim antara anak dan orang tua serta bentuk komunikasi dua arah yang baik merupakan kunci keberhasilan pendidikan di keluarga (Herliyanawati, 2017).

Hariring indung sudah mulai dilantunkan sejak bayi dalam buaian ibu. Biasanya seraya ngahariring ibu pun mengusap kepala ataupun bagian tubuh dari sang bayi ataupun anak usia dini sehingga interaksi yang terjadi bukan hanya secara verbal saja tetapi nonverbal pun terbangun dengan baik. Berdasarkan data di lapangan hanya $45 \%$ ibu-ibu yang melakukan hariring disertai usapan lembut pada sang anak, 35\% nya mengatakan kadang-kadang dan 20\% lainnya menyatakan tidak pernah. Penekanan pada interaksi ini merupakan asumsi sebagian orang dewasa dan anak-anak yang lebih dewasa, bahwa perilaku respon dan ujaran yang spontan pada bayi memiliki makna (Otto, 2015). 


\section{Tindakan yang dilakukan Ibu saat melakukan hariring indung}

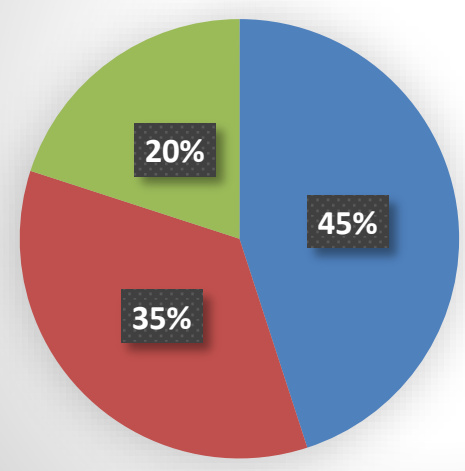

- Sambil mengusap lembut

- kadang-kadang sambil mengusap lembut

- Tidak pernah sambil melakukan apapun

Gambar 2: Tindakan yang Dilakukan Ibu saat Melakukan Hariring Indung

Kegiatan hariring indung yang dibangun dengan baik oleh seorang ibu dapat menjadi jembatan untuk berkembangnya pemerolehan bahasa anak. Pemerolehan bahasa anak merupakan hal yang penting bagi terbangunnya komunikasi antara orang tua dan anak. Ketika anak sudah memiliki kekayaan kosa kata, tentu tidak akan sulit dalam mengomunikasikan perasaan dan pemikirannya. Tingkat pembelajaran kata berhubungan dengan tingkat keseringan percakapan orang tua kepada anak dan juga beragam kata yang digunakan dan bagaimana katakata baru ditampilkan (Otto, 2015). Sebagaimana yang dilakukan ibu-ibu di Desa Lamajang, Kecamatan Pangalengan, Kabupaten Bandung yang sebagian besar masih mempertahankan tradisi hariring sambil anak beraktivitas yang lain. $40 \%$ ibu sering melakukan hariring sambil menemani anaknya bermain, 31\% kadangkadang melakukannya, dan $29 \%$ tidak pernah melakukannya.

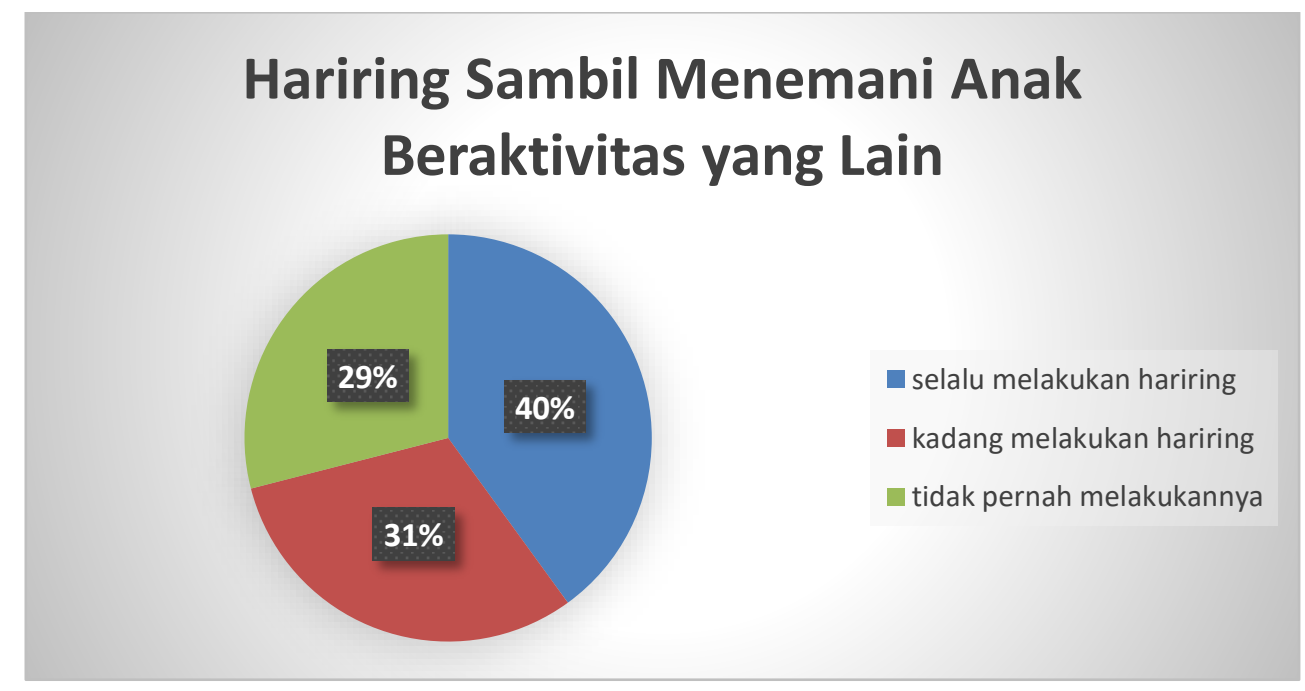

Gambar 3. Hariring sambil Menemani Anak Beraktivitas yang Lain 
Dari gambar diagram mengenai kegiatan hariring yang ibu lakukan, terlihat persentase cukup besar yang menunjukkan bahwa ada $29 \%$ yang sudah tidak melakukan lagi hariring ketika anak beraktivitas. Di masa sekarang, walaupun ada di daerah kabupaten Bandung, terpaan gadget dan media sosial sangat terasa. Zaman dahulu, pada tradisi Sunda ada istilah istri binangkit yang lihat dan prigel membuat aneka kreativitas, seperti memasak, menjahit, menyulam, memainkan alat musik tradisional, dan lain-lain. Kini, para ibu disibukkan dengan telepon genggam dan media sosial berbasis chatting seperti WhatsApp ketika mengisi waktu luang. Jadi, ketika anak sedang beraktivitas lain seperti bermain atau mengerjakan PR, para ibu menggunakan aktivitas itu untuk chatting, Padahal, jika digunakan untuk hariring saja, anak tentu akan merasa ditemani dan didoakan setiap waktunya karena sebagian besar isi dari hariring indung dalam tradisi Sunda adalah doa yang dipanjatkan untuk anak.

Sebagai contoh ada hariring yang berjudul "Nimang". Posisi ibu ketika melakukan hariring untuk "Nimang" sangat dekat dengan anak, seperti menggendong, memeluk, atau membelai. Komunikasi nonverbal meliputi ekspresi wajah, nada suara, gerakan anggota tubuh, kontak mata, rancangan ruang, dan tindakan-tindakan nonverbal lainnya yang tidak menggunakan kata-kata (Liliweri, 2013). Komunikasi nonverbal sangat erat terikat dengan kultur tertentu. Oleh karena itu, hal yang dilakukan ibu saat melantunkan lagu sejenis hariring indung di daerah lain, tentu tidak dapat dimaknai sama. Jika di tanah Sunda, melantunkan hariring sambil menggendong bayi menggunakan kain dan ibu berdiri bergoyang perlahan dimaksudkan agar bayi cepat tertidur, di daerah lain belum tentu memiliki maksud yang sama. Berikut adalah lirik dari hariring "Nimang" dalam tradisi hariring di tanah Sunda.

Nimang
Nelengnengkung-nelengnengkung
Geura gede geura jangkung
Geura nyiar elmu luhung
Geura mika nyaah indung
Dun ta patung tung cipandan
Dugi kana babantana
Cintana indung ka anakna
Sesah milari pantana
Nalanglangtung tung cipandan
Leubas nian sagarana
Melangna indung ka anak
Langkung ti ka salirana

Lirik hariring nimang berisikan tentang nasehat dan doa seorang ibu terhadap anaknya, agar sang anak segera beranjak dewasa, segera mampu menjadi ilmuan, dan menjadi orang besar. Pada lirik ini, sang ibu tidak lupa mengingatkan bahwa kasih sayangnya untuk anak tiada pernah dapat tertandingi. Hal ini 
menjelaskan bahwa hariring indung selain mampu membangun komunikasi yang baik antara ibu dan anak, sarat dengan muatan moral yang berupa nasihat serta doa untuk sang anak.

\section{Ibu yang Melakukan Hariring Nimang}
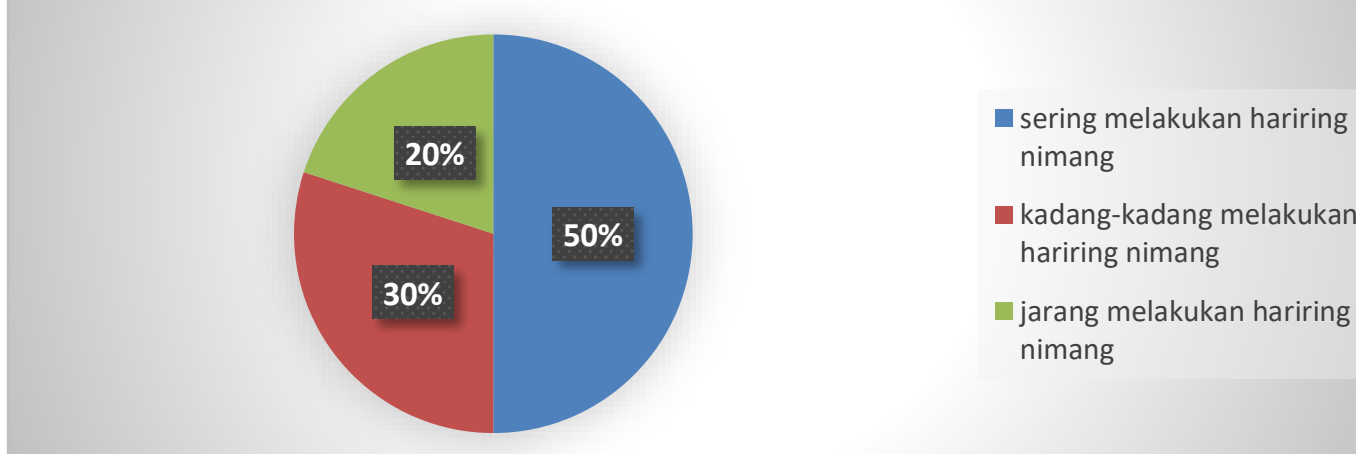

Gambar 4: Ibu yang Melakukan Hariring Nimang

Data yang diperoleh, ada 50\% ibu masih sering melakukan hariring "Nimang" untuk anak-anaknya. "Nimang" dikenal juga dengan "Nelengnengkung". Namun, ada 30\% ibu kadang-kadang melakukan hariring "Nimang", dan $20 \%$ sudah tidak pernah melakukannya. Walaupun tidak pernah melakukan, bukan berarti tidak berdoa untuk kebaikan anak-anak, tetapi "Nimang" tidak dinyanyikan saja, diganti dengan lagu lain yang lebih dihapal. Apalagi, ibuibu muda yang merupakan generasi milenial, sudah jarang mengetahui hariring "Nimang". Mereka biasanya memilih lagu lain atau cara lain untuk mendoakan anaknya.

Membangun komunikasi antara ibu dan anak bukan hanya melalui percakapan saja tetapi bisa melalui berbagai hal yang dekat dengan dunia anak salah satunya melalui hariring indung. Melalui hariring, anak akan merasa nyaman dan aman karena sambil melakukan hariring. Ibu pun menyentuh dan membelai sekaligus melakukan interaksi langsung berupa tanggapan terhadap ocehan yang keluar dari mulut anak.

Hariring sering dilakukan ibu-ibu karena bisa dilakukan sambil beraktivitas lain ataupun ketika anak melakukan kegiatan lain. Terkadang, ibu-ibu menciptakan sendiri lirik hariring-nya sesuai dengan topik yang ingin disampaikan kepada anak. Jadi, seolah-olah ibu bercakap-cakap dengan anak melalui hariring. Anak pun akan merespons ketika menarik minatnya. Misalnya, dari hariring "Nimang", ada klausa "geura gede geura jangkung", anak acapkali bertanya "mun tos ageung bakal jangkung, nya?" yang artinya "kalau sudah besar akan tinggi, ya?" dan lain-lain. Namun, ibu-ibu mengakui merasa nyaman melakukan hariring ketika dalam suasana santai, tidak sambil beraktivitas lain yang berat.

Berdasarkan survei, 86\% ibu mengajak anak bercengkrama sambil sekalikali ngahariring, 3\% ibu jarang melakukan hariring saat bercengkrama, dan $11 \%$ tidak melakukan hariring saat bercengkrama. Bukan hal yang aneh jika sebagian besar ibu-ibu di Desa Lamajang tersebut masih membiasakan hariring sambil 
Andalusia Neneng Permatasari, Dinar Nur Inten: Hariring Indung Sebagai Media Komunikasi Ibu dan Anak Usia Dini

bercengkrama dengan anak untuk menyampaikan pesan atau nasihat karena bagi anak usia dini daripada instruksi, pesan melalui nada yang menyenangkan hatinya akan jauh lebih dapat diterima. Proses ibu melakukan hariring sambil menyelipkan dapat dimaknai sebagai bentuk komunikasi. Saat anak mendengarkan hariring, dia berperan sebagai penerima pesan, baik memberikan feedback secara langsung ataupun tidak. Musik, nada, dan lirik lagu memiliki muatan berupa nilai-nilai tertentu yang akan diterima khalayak dan diturunkan dari satu generasi ke generasi berikutnya (Yuliarti, 2015).

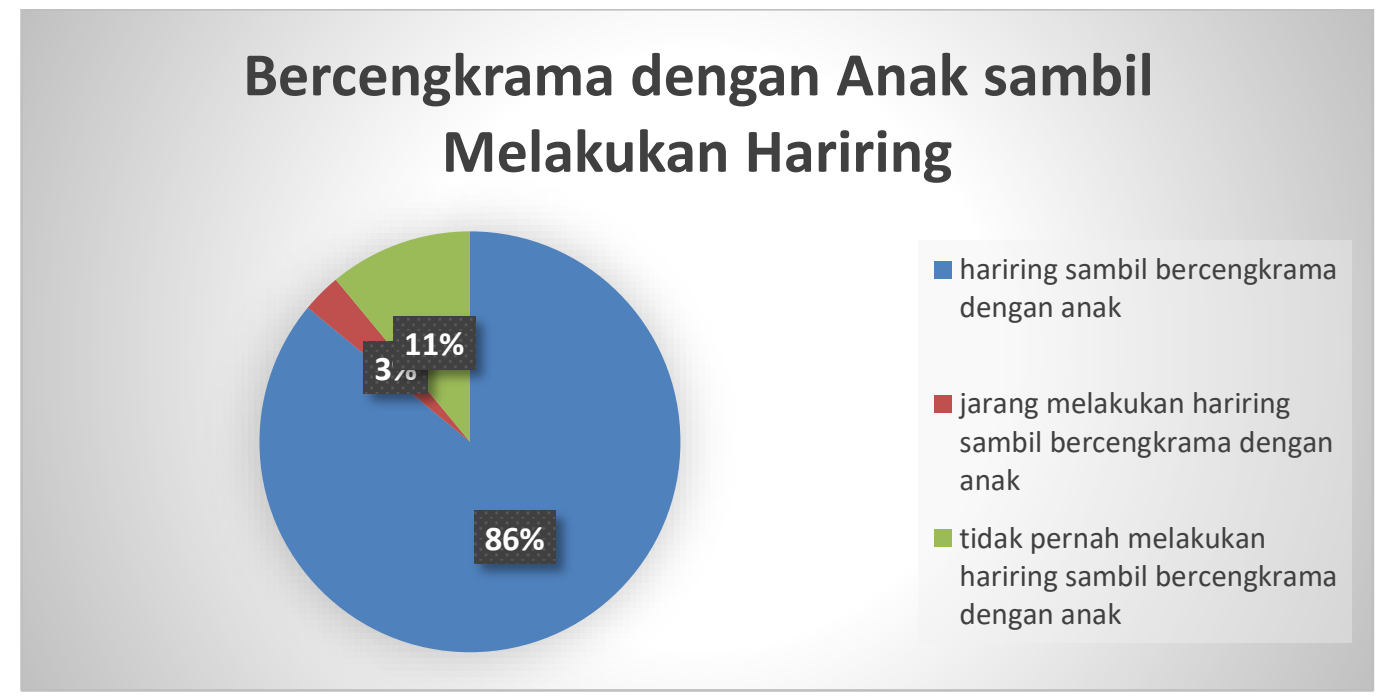

Gambar 4. Ibu Bercengkrama sambil Hariring

Selain sambil bercengkrama, ibu-ibu melakukan hariring untuk anaknya ketika menjelang tidur. Berdasarkan data responden, $70 \%$ ibu sering melakukan hariring menjelang tidur, $20 \%$ responden ibu-ibu jarang melakukan hariring menjelang tidur, $10 \%$ tidak pernah melakukan hariring menjelang tidur. Ibu yang sudah tidak pernah melakukan hariring jelang tidur karena biasanya anak sudah tidur terlebih dahulu atau membiarkan anak tertidur sambil menonton televisi. Padahal, jika anak dinyanyikan hariring menjelang tidur, selain bounding dengan anak terbangun, anak juga akan belajar dengan emosinya karena lagu sangat berperan penting dalam kondisi emosi yang mendengarnya (Yuliarti, 2015). 


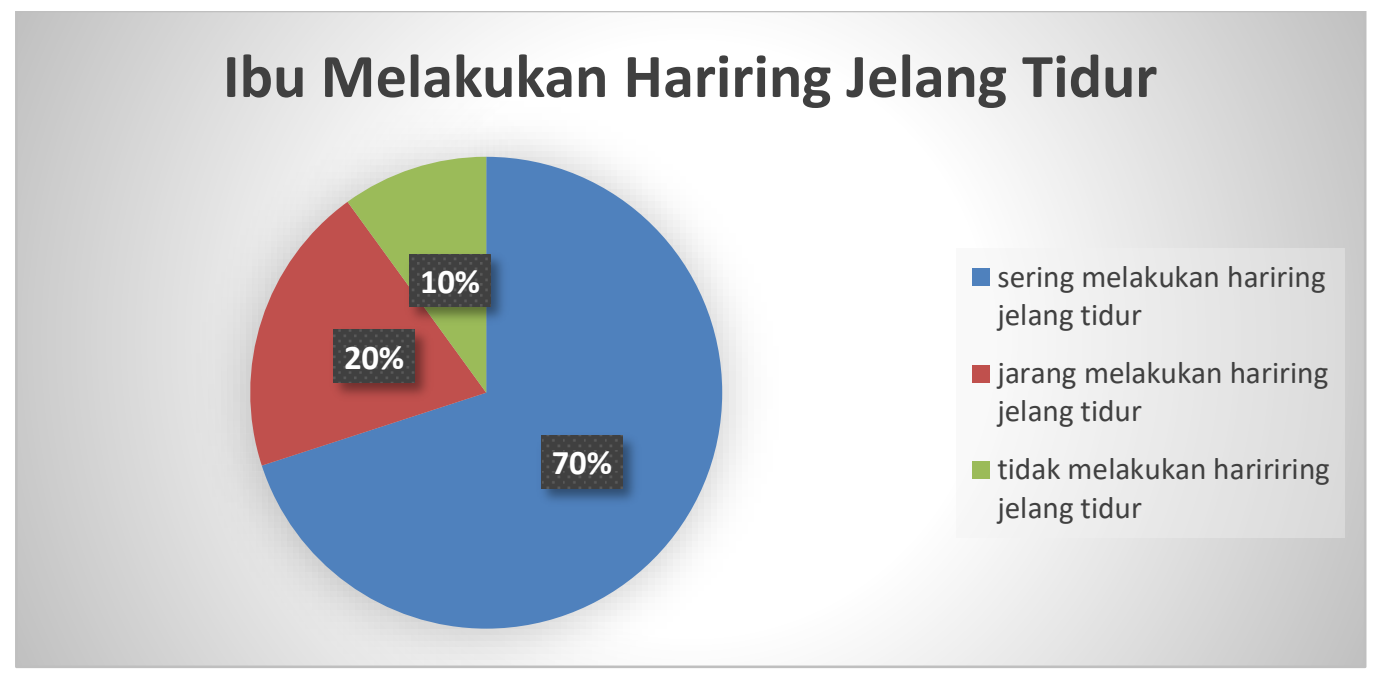

Gambar 5. Ibu Melakukan Hariring Jelang Tidur

Ketika mengantar anak tidur, ibu memang sering menemani anak terlebih dahulu. Aktivitas yang ibu lakukan bersama anak menjelang tidur biasanya membacakan cerita atau menyanyikan lullaby. Lullaby dalam tradisi Sunda pun hariring indung itu sering digunakan para ibu untuk mengantarkan dan menemani anaknya tidur. Hariring di bawah ini berjudul "Ayun Ambing” ciptaan Mang Koko. Hariring ini dilantunkan ibu ketika mengayun atapun membelai-belai anaknya menjelang tidur.

\section{Ayun kusamping, ayun ambing Bobo sing tibra, ulah rungsing \\ Utun dijaring, ayun ambing \\ Bobo diaping, beurang-peuting \\ Bobo anaking, ayun ambing \\ Kulem sing tibra, masing jeumpling}

Anak-anak terlahir dengan kecenderungan memperhatikan bunyi atau bahasa yang ada di sekitar lingkungannya, apalagi anak usia dini lebih cenderung menyukai bunyi dari manusia dari pada benda yang lain. Bunyi atau suara yang sangat disukai oleh sang bayi adalah suara ibunya (Otto, 2015). Ketika ibu berhariring, lirik hariring disampaikan dengan intonasi yang jelas dan mimik atau bahasa tubuh yang sesuai karena melalui ujaran yang ekspresif dan beragam secara intonasi akan semakin menarik perhatian anak. Melalui pengamatan, memberikan waktu untuk merespon dan mendengarkan serta pengulangan pada kata-kata tertentu akan menambah terjalinnya komunikasi yang optimal.

Hariring indung memiliki syair lagu yang sederhana, rima yang berulang, dan tidak terlalu cepat. Hal ini memberikan kesempatan bagi anak-anak untuk lebih memahami bunyi, rima, dan ritme. Lagu dan permainan jari yang disertai nyanyian dapat membantu berkembangnya kemampuan mendengarkan dan meniru bahasa tubuh. Pada usia ini lagu nyanyian dan hariring dapat pula dikaitkan dengan menghubungkan nama-nama kata dengan benda di sekitarnya (Otto, 2015). Anak 
Andalusia Neneng Permatasari, Dinar Nur Inten: Hariring Indung Sebagai Media Komunikasi Ibu dan Anak Usia Dini

pun senantiasa merespon hariring indung yang dilantunkan ibunya. Berikut tabel yang memperlihatkan responsa anak terhadap hariring indung yang dilantunkan oleh ibu-ibu muda di Desa Lamajang, Kecamatan Pangalengan, Kabupaten Bandung.

Tabel 1. Respons Anak Usia Dini terhadap Kegiatan Hariring Indung

\begin{tabular}{ll}
\hline \multicolumn{1}{c}{ Kegiatan Hariring Indung oleh Ibu } & \multicolumn{1}{c}{ Respons Anak Usia Dini } \\
\hline $\begin{array}{l}\text { Ibu melantunkan hariring pada setiap } \\
\text { aktivitas bersama anak }\end{array}$ & $\begin{array}{l}\text { Anak ikut aktif di dalam percakapan, baik } \\
\text { verbal atau non-verbal. }\end{array}$ \\
\hline $\begin{array}{l}\text { Ibu mengusap kepala anak atua bagian } \\
\text { tubuh lain sambil melantunkan hariring }\end{array}$ & $\begin{array}{l}\text { Tidak saja ikut aktif secara verbal atau non- } \\
\text { verbal, tetapi keintiman komunikasi pun } \\
\text { terjalin sehingga anak merasa nyaman, } \\
\text { bahkan ada yang sampai tertidur. }\end{array}$ \\
\hline $\begin{array}{l}\text { Ibu melantunkan hariring di sela-sela } \\
\text { mengawasi anak bermain dengan anak } \\
\text { sambil menyelipkan nasihat }\end{array}$ & $\begin{array}{l}\text { Anak lebih siap menerima dan menyimak } \\
\text { nasihat karena tidak berupa instruksi, } \\
\text { melainkan dengan nada-nada yang akan } \\
\text { membuat hati anak lebih gembira. }\end{array}$ \\
\hline Ibu hariring $\quad$ saatantunkan & $\begin{array}{l}\text { Anak akan memiliki kosa kata yang cukup } \\
\text { kercengkrama sehingga anak lebih mudah } \\
\text { mengomunikasikan emosi, perasaan, dan }\end{array}$ \\
& gagasannya. \\
\hline Ibu membiasakan hariring secara rutin & $\begin{array}{l}\text { Ada banyak yang tercukupi dengan } \\
\text { kegiatan hariring: keintiman ibu dan anak, } \\
\text { pesan yang menyenangkan diterima anak, } \\
\text { kosa kata yang memperkaya dan membantu } \\
\text { perkembangan bahasanya, sampai } \\
\text { kestabilan emosi anak karena merasa } \\
\text { ibunya selalu ada untuk dia. }\end{array}$ \\
\hline
\end{tabular}

Hariring indung selain menggunakan bahasa verbal, juga menggunakan bahasa tubuh simbolik ketika berbicara atau ngahariring hal ini dapat mendorong anak untuk menggunakan bahasa tubuh dalam mengekspresikan keinginan dan kebutuhannya, sehingga interaksi antara anak dengan orang dewasa dapat terjalin dengan optimal. Melalui bahasa tubuh simbolik pun dapat memperjelas arti atau makna dari kata-kata yang disampaikan. Hariring indung mengomunikasikan perasaan ibu dan anak dengan verbal dan nonverbal serta dengan menggunakan bahasa ibu yang diikuti dengan bahasa tubuh akan menambah kebermaknaan hariring indung dalam membangun terjalinnya komunikasi yang baik antara ibu dan anak.

\section{Simpulan}

Keutamaan ibu membawa peran ibu sangat penting dalam kehidupan dan masa depan seorang anak. Tutur kata yang baik membawa hariring seorang ibu yang berupa nasihat dan doa-doa yang dilantunkan di saat sang anak kecil menjadi alat untuk membangun komunikasi yang sangat erat, penuh kasih sayang dan sesuai dengan perkembangan anak sehingga lirik hariring yang dilantunkan dapat menjadi pijakan untuk awal perjalanan dan gambaran masa depan anak. 
Hariring indung memperkaya kegiatan komunikasi seorang ibu bukan sekadar ucapan atau verbal tapi dilengkapi pula dengan balutan kasih sayang melalui belaian yang dapat langsung dirasakan anak dan masuk ke bawah alam sadarnya sehingga hal tersebut akan membekas, disimpan, kemudian dilakukan kembali kelak ketika ia dewasa. Melalui hariring indung yang dibudayakan kembali selain bertujuan untuk mempererat komunikasi ibu dan anak, misi yang tak kalah utama yaitu untuk melestarikan budaya Sunda sebagai bahasa ibu orangorang yang tinggal di tatar Sunda.

Penelitian ini masih dapat dilanjutkan dengan mengeksplorasi lagi kekayaan kearifan lokal di setiap daerah di Indonesia. Hal itu dapat memperkaya wawasan parenting sekaligus media komunikasi ibu dan anak yang kental nuansa lokal dan kemungkinan besar relevan dengan karakteristik masyarakat dan pola asuh keluarga di Indonesia.

\section{Ucapan Terima Kasih}

Penulis mengucapkan terima kasih kepada seluruh pihak yang telah membantu. Ucapan terima kasih juga penulis sampaikan kepada ibu-ibu dari siswa usia dini yang bersekolah di R.A. Al-Muqoddasah, Desa Lumajang, Kecamatan Pangalengan yang telah membantu penelitian ini. Penulis juga mengucapan terima kasih kepada redakasi JURNAL KOMUNIKASI yang telah memberi kesempatan pada penulis untuk berbagi ilmu.

\section{Daftar Pustaka}

Badan Pusat Statistik. (2015). Mengulik Data Suku di Indonesia. Www.Bps.Go.Id. https://www.bps.go.id/news/2015/11/18/127/mengulik-data-suku-diindonesia.html

Bahri, H. (2018). Strategi Komunikasi terhadap Anak Usia Dini. Nuansa, XI(1), $48-58$.

Herliyanawati, Di. (2017). Komunikasi Antar Pribadi Ibu kepada Anak ( Studi Deskriptif Kualitatif Komunikasi Ibu Kepada Anaknya yang Disekolahkan di Pondok Pesantren dalam Membangun Motivasi Belajar Anak ). Universitas Muhammadiyah Surakarta.

Inten, D. N., Permatasari, A. N., \& Mulyani, D. (2016). Literasi Dini Melalui Teknik Bernyanyi. 3(2013), 70-91.

Istadi, I. (2012). Ayo Bicara. Pustaka Inti.

Liansari, V. (2017). Pola Komunikasi Interpersonal Orang Tua dan Anak Usia Dini dengan Speech Delay di TK Aisiyah Rewwin Waru. Kanal (Jurnal Ilmu Komunikasi, 5(2), 159-164. https://doi.org/https://doi.org/10.21070/kanal

Liliweri, A. (2013). Dasar-Dasar Komunikasi Antar Budaya. Pustaka Pelajar.

May, B. N. (2020). The Rhyme and Reason for Nursery Rhymes in the Elementary Music Classroom. General Music Today, 33(2), 90-96. https://doi.org/1o0i..o1r1g/7107.1/17074/18034873173131198800878575

Nurgiantoro, B. (2016). Sastra Anak. Gadjah Mada University Press. 
Andalusia Neneng Permatasari, Dinar Nur Inten: Hariring Indung Sebagai Media Komunikasi Ibu dan Anak Usia Dini

Nurhadi, Z. F. (2015). Komunikasi Keluarga Sabeulah dalam Konteks Kesundaan. Jurnal Komunikasi, 6(3), 44-58. https://doi.org/http://dx.doi.org/10.24912/jk.v6i3.39

Otto, B. (2015). Perkembangan Bahasa pada Anak Usia Dini. Kencana.

Permatasari, A. N. (2017). Representasi Anak pada Film Perang (Analisis Semiotika pada Film Life is Beatiful dan The Boy in The Stripped Pajamas). GOLDEN AGE: JURNAL PENDIDIKAN ANAK USIA DINI. https://doi.org/10.29313/ga.v1i1.2587

Permatasari, A. N., Inten, D. N., Mulyani, D., \& Rahminawati, N. (2017). Literasi Dini Dengan Teknik Bercerita. FamilyEdu, 3(1), 20-28.

Putri, A. R., Farida, Y. E., \& Sa'idah, N. (2018). Improving Young Learner's Listening Skill By Using Nursery Rhymes Song. Journal of English Teaching and Learning Issues, 1(2), 20-41. https://doi.org/http://dx.doi.org/10.21043/jetli.v1i2.3843

Rachmani. (2008). Keterampilan Musik dan Seni. Universitas Terbuka.

Riza, E. (2016). Pengaruh Komunikasi Interpersonal Ibu dan Anak terhadap Kemampuan Berbicara Anak Studi Ex Post Facto Anak Usia 4-5 Tahun Pada Kelompok A Taman Kanak Kanak Islam Kelurahan Pondok Bambu Jakarta Timur. Jurnal Ilmiah Pendidikan, 6(1), 1-7.

Setiaji, D. (2017). Pembelajaran Lagu Oray Bungka. Jurnal Pendidikan, 1(1), 112.

Sumantri, M., Djamaludin, A., Patoni, A., Koerdi, M. R. A., Koesman, M. ., \& Adisastra, E. S. (1985). Kamus Sunda Indonesia. Pusat Pembinaan dan Pengembangan Bahasa Departemen Pendidikan dan Kebudayaan.

Triwardhani, I. J. (2009). 22 Prinsip Komunikasi Efektif untuk Meningkatkan Minat Belajar Anak. Simbiosa Rekatama Media.

Welianto, A. (2020, January 4). Daftar Suku Bangsa di Indonesia. Kompas.Com. https://www.kompas.com/skola/read/2020/01/04/210000869/daftar-sukubangsa-di-indonesia?page $=$ all

Yuliarti, M. S. (2015). Komunikasi Musik: Pesan Nilai-Nilai Cinta dalam Lagu Indonesia. ILMU KOMUNIKASI, 12(2), 189-198. https://doi.org/doi.org/10.24002/jik.v12i2.470 